\title{
There's no welcome like an Indian welcome
}

\author{
EUNICE TUdELA DE AZEVEDO E JOANA PAJUELO ALVES
}

Pune (India). 1-12 November 2017. IAPAR International Theatre Festival.

In the summer of 2017 we were looking for a challenge. It came in the form of an invitation by the International Association of Theatre Critics (IATC) for a Young Critics' seminar promoted by IAPAR (International Association for Performing Arts and Research), the Indian Centre of ITI (International Theatre Institute) and the Indian National Section of IATC in the International Theatre Festival in Pune, Maharashtra. Neither of us had ever been to India. We were curious, nervous and excited: the perfect blend for an adventure. It began in Lisbon, on November $3^{\text {rd }}$ and after three flights, more than 24 hours and a car ride later, we arrived at IAPAR's headquarters for a delicious meal and a session about poetry in translation. This session was our first contact with two of the 22 official languages of India - Urdu and Gujarati - and the plurality of art forms that made up the festival's programme. The festival ran from the $1^{\text {st }}$ to the $12^{\text {th }}$ of November 2017 and the seminar from the $5^{\text {th }}$ to the $9^{\text {th }}$. The theme was "Actor at the Centre" and featured performances from Argentina, Bangladesh, Germany, Korea, Sri Lanka, Turkey, Italy and India. It offered several workshops with art practitioners and educators, music sessions, dance, theatre and performances.

The daily schedule was reasonably intense since the seminar lasted all morning and there were several performances throughout the evening and night. After the seminar sessions, we tried to discover Pune by walking around and sightseeing until it was time to head out to Jyostna Bhole Sabhagruha, the cultural centre that hosted all productions. The platform performances took place on the ground floor every day at $6 \mathrm{pm}$ and were very diverse, ranging from contemporary to traditional music, dance and theatre. Afterwards we would go up to the main venue, on the second floor, to attend the leading performances of the evening (from $7 \mathrm{pm}$ to $9 \mathrm{pm}$ ) which were followed by a conversation with the artists. A meal was then offered in the terrace to all the people involved in the festival and this moment provided the opportunity to share stories and experiences 
and talk about the artistic, political and social realities of India and of our colleagues' countries of origin.

On our first day, after the session "Poetry in translation", we attended the presentation of the new album As written in the stars by the Easy Wanderlings, a young band from Pune. In the evening, we saw Mandragora Circus, by Mandragora Circo (Argentina), a nonverbal production about comedy and love performed by two clowns who were very successful in engaging with the audience. Circus stunts, gags, music and unconventional instruments created an environment of tenderness and simplicity that appealed to all ages.

In the afternoon of the second day there was a production from the Korean Theatrical Company ENSEMBLE named Hole which explored different ways of dealing with a specific problem: the sudden appearance of a hole on the ground. One of the protagonists wanted to thoroughly investigate its causes while the other simply wanted to cover it up. It stood as a metaphor for the political situation in South Korea in 2016 (Candlelight Revolution) and was revealed by the director to have had substantial resonance with the public serving as a trigger for the protests. This was followed by the delightful recital Bhojpuri Folk Songs, by Kumar \& Akhil Tiwari, a traditional music form of the state of Bihar, originally sang by the Kabirpanthi. The main performance was the monologue It's me, Edith Piaf, by Internationales Berliner Drama Theatre from Germany, based on the singer's life, from her troubled childhood to stardom, and had several music interludes where the protagonist sang some of Piaf's hits.

On the following day, there was a Thala Dance performance by Naadeeka Tharangani, from Sri Lanka, that depicted the birth of a child in a post-war world and the struggle to create a real bond in a society branded by violence and loneliness. The main performance was the impressive Elephant In The Room, by the Dur Se Brothers (India), written by Sneh Sapru and conceived, directed and performed by Yuki Ellias. This intense and dynamic performance was based on the story of the Hindu god Ganesha, who was created from clay by the goddess Parvati and is here personified by the young Master Tusk. Ganesha, whose iconography is that of a human body with an elephant's head, is the obstacle-removing god of new beginnings and patron of the arts and science. His myth was treated in an unconventional way in this performance, because rather than telling the traditional tale of the god's origin, the focus was on what might have happened following the young boy's beheading by 
the god Shiva who, in a fit of rage, failed to recognize him as kin. Yuki, the sole performer, through the fusion of Koodiyattam, a classical dance form from Kerala, and Lecoq technique, was capable of simultaneously narrating and portraying the wide range of characters needed to tell Master Tusk's adventure of turbulent self-discovery after finding himself lost in the forest while searching for his severed head. Her expressiveness and ability to differentiate the various characters through posture and voice were complemented by the very well executed and mutating costume composed by kimono and balloon trousers, with Japanese and Indian influences, in shades of red, black and grey. This beautiful coming-of-age story is, foremost, a metaphor for an identity crisis and the subsequent process of developing self-knowledge which appeals to children as well as adults. It also deals with the implications of climate change by establishing a parallel between the animals driven out of their native land due to its destruction by the gods and the indigenous people and farmers being stripped of their territories and livelihood in India. This social and political critique of the dominant ruling class and the voicelessness of the disadvantaged is eroded by the performance's appeasing end, which constitutes its only flaw.

November $7^{\text {th }}$ began with an experimental performance from Bangladesh, Rupchan Sundarir Pala, written and performed by Sayik Siddiquee. Presented in the form of a ballad in which the portraying of nine characters and storytelling are blended together in the body of the performer who acts, sings, dances and narrates the story of a beautiful young girl with a dreadful fate. Serious attention to physical and verbal detail was given by Sayik in this very interactive performance that relied on audience members as dancing partners. Two main performances were carried out that evening: a dance production based on everyday movements of bodies in urban centres called In Transit, by IAPAR (India) with concept and direction by Aditi Venkateshwaran, and a play performed in Hindi, Venunad by Rangayug Sanskrutik Sansthan (India), conceptualized and performed by Ashwini Giri, that explored Krishna's identity and his relationships with several women. The language barrier and the stylization of movement made it a very inaccessible production to a non-Indian audience.

On the fifth day of the seminar, we attended a platform performance by Aniruddah Deodhar, one of the drama students who presented the audience with an accomplished Nyukhin of Tchekov's On the harmful effects of tobacco. Swing of Love, the main performance, a co-production 
by Inter Act Art (Sri Lanka) and Itinera - Arte en Expansión (Italy), announced itself as a reinvention of femininity performed solely on swings. Being a condescending male approach on the subject, it seemed to us to reinforce stereotypes. It was also a misuse of a good physical performer and promising set design. On the other hand, it contributed to a very passionate discussion about preconceptions of womanhood and women's rights in the seminar's context.

The last day of our attendance featured another platform performance, The Sneeze, written by Neil Simon after Chekhov's work, by the able student ensemble Lalit Kala Kendra Gurukul (India), and the main production, Party, by Maharashtra Cultural Centre (India), a fulfilling mise-en-scène of the homonymous play by the Marahti author Mahesh Elkunchwar, one of the countries' most influential playwrights. This good performance, based on the 1976 satire, gave the audience a glimpse of the cultural and social habits of Mumbai's elite through the course of a troubled party that, as we were told, still uphold today. The plot revolved around the gathering of artists, art patrons and socialites to celebrate an award-winning novelist but the party is haunted by the absence of a promising poet who became a political activist. Constantly brought up in conversation, the hero-poet exposes the hypocrisy of Mumbai's wealthy and intellectual society in this social commentary drama that ends with the news of him being shot down by the police in a protest.

All these performances were discussed in the seminar sessions meticulously conducted by Deepa Punjani in collaboration with Ajay Joshi. Deepa Punjani has been engaged with theatre and theatre criticism for almost 20 years and is the founder of the Indian National Section of IATC and chief editor of the Mumbai Theatre Guide. She directed this seminar with a delicate balance between the aspects associated with the work of the theatre critic, his relationship with the artists, his role as a specialized spectator, and the honest and objective analysis of performances in a technical, conceptual and ideological way. Dr. Ajay Joshi is a founding member of IAPAR, a member of the Indian Society for Theatre Research and of the Indian National Section of IATC and has been a freelancer for major Indian and international newspapers, magazines and journals on theatre and culture. He is also deeply involved with the artists and their production conditions and with matters related to freedom of speech, freedom of the press and its status in Indian society.

We started by addressing the role of the critic and criticism in the artistic community and society in general and the formal and structural 
aspects of theatre criticism and cultural journalism. After this theoretical introduction, we talked about what we had seen the day before. The debate around performances was greatly enriched by the personal backgrounds and various places of origin of the participants, since there were people from Serbia, Taiwan, Hong-Kong, Canada, India, Czech Republic and Portugal. It was interesting to notice the differences in approaching performances, as some of us were more interested in the technical features, while others were more ideologically and politically oriented. This was an important contribution to performance analysis and productive conversation from different points of view. During the seminar, we were also introduced to notions about Indian and Marathi theatre, especially during the visit of Aditi Sharma, a guest speaker who is a theatre critic and assistant editor at Pune's section of The Times of India. Other guests were Péter Valcz and Orsolya Juhász from Hungary, who presented us with their project "Workship", a non-profit artist run research center on the Danube, and a short workshop on Lecoq's method.

Led by the very friendly festival director Vidyanidhee Varanase - affectionately called Prasad -, the staff and volunteers that welcomed and helped us were one of the most fulfilling and soulful parts of our experience. The volunteers were people from multiple contexts who showed remarkable patience and generosity in answering our questions about India's reality. (We would like to believe we answered at least some of their questions about Europe as well.) They were mainly theatre students in Pune and the unity we felt between them was promoted, perhaps, by the structure of their theatre programme. All of them had to assume the different roles of a theatre production in each other's final assessment: they wrote, directed, acted and managed lighting, costumes and sets for each other's plays. This kind of dynamic appears to be a compelling way of working and learning the practice, because not only it allows the students to experience the challenges of each function, but also paves the way for a deeply respectful connection with everyone's aesthetic ideas within the group, which they kindly shared with us.

We had the opportunity to discover a "new" kind of theatre based on a radically different cultural heritage that regards and honors physicality and expressiveness as a meticulously executed discipline. This results in a plurality of performance languages with regional and religious specificities built mainly upon the tradition of gesture and body. This focus on the disciplined body and the repetition of themes taken from the sacred books resonates in the actor's and dancer's status within society. 
Unlike the Western tradition of the proscribed actor/dancer, the performer in India is an esteemed figure due to the mastery of his craft.

We are extremely grateful that IAPAR International Festival made this wonderful learning experience possible for us and contributed to the painting of a bigger picture when it comes to the practice of theatre in the world. The plurality of its programme promotes cultural and artistic exchange in a friendly and generous environment, which we found to be enriching and defying of our eurocentric notions. By bringing together people from such diverse nationalities, areas of knowledge and different schools, methods and aesthetical approaches, in a setting as seductive and challenging as India, this festival creates a unique and unpretentious theatre community. 